\title{
MASALAH DAN TANTANGAN PENGEMBANGAN KEWIRAUSAHAAN PADA KALANGAN MAHASISWA DI INDONESIA
}

\author{
Imam Santosa \\ Universitas Jenderal Soedirman
}

Email: Scokronegoro@yahoo.com,imamsantosa@unsoed.ac.id

\begin{abstract}
Indonesian nation face some important and crucial problem about poverty. One of which's to overcome the amount of unemployment. It's still relatively high plus the total labor force continues to grow each year. One thing is needed that number of entrepreneurs should be raised. Because of it as one of the indicators of economic progress. A number of obstacles facing, such as: social and economic constraints and market structure have not yet accomodate for conducting this. However, with improving education policy, curriculum and learning systems (students and lecturers relations) that can foster the emergence of a stimulus for innovation and creativity is convinced that these obstacles can be overcome.
\end{abstract}

Keywords: SMEs, pooled data, fixed effect

\section{PENDAHULUAN}

Benyamin Franklin menyebutkan peranan pemuda sangat strategis dan urgen. Pemuda menurut Franklin adalah kelompok orang yang akan menjadi pemimpin bangsa di masa depan ("who will become national leaders in the future"). Mahasiswa sebagai bagian dari pemuda termasuk modal dasar untuk pengembangan pemecahan ragam masalah bangsa; bukan sebaliknya justeru menjadi problem dari bangsa ini. Terlebih jika mengingat dunia ketenagakerjaan yang belum menjamin ketersediaan lapangan pekerjaan yang memadai bagi mahasiswa khususnya saat usai menyelesaikan masa studi.

Persoalan penyediaan lapangan pekerjaan menjadi salah satu masalah mendasar dalam pembangunan nasional berkelanjutan. Hal tersebut erat kaitannya dengan kenaikan intensitas persoalan pengangguran. Tingkat pengangguran untuk angkatan kerja Indonesia relatif masih tergolong tinggi. Pada Tahun 2012 terdapat 7,3 juta atau sekitar 6,14 persen dari total angkatan kerja yang masih berstatus menganggur (BPS dan SUKERNAS, 2012). Seiring dengan hal tersebut, kondisi lain yang juga memprihatinkan tampak bahwa pada Tahun 2014 terdapat 28 juta orang penduduk Indonesia yang masuk kategori miskin. Deretan persoalan nasional yang tak kalah penting terkait dengan kemunculan angkatan kerja baru (new labor force) yang terus bertambah antara dua sampai tiga juta orang per tahun (Suryana dan Bayu, 2013). Tentu saja persoalan tersebut tidak dapat dibiarkan berlangsung terus. Salah satu solusi yang perlu dikedepankan ialah mengembangkan jiwa, semangat dan perilaku kewirausahaan pada berbagai kalangan anggota masyarakat khususnya mahasiswa sebagai bagian dari generasi muda penerus cita-cita bangsa dan negara.

Pengembangan kesadaran dan motif kewirausahaan pada kalangan mahasiswa merupakan suatu kebutuhan mendasar untuk 
mencapai peningkatan kualitas sumberdaya manusia agar nantinya selain terlahir sebagai insan terdidik juga berkarakter mandiri, ulet, bekerja keras, pantang menyerah, bertanggungjawab, berani menanggung risiko, bermotif ekonomi, menghargai waktu dan memanfaatkan setiap kesempatan, produktif, kreatif dan inovatif. Kengembangan kewirausahaan pada kalangan mahasiswa memerlukan ragam terobosan jitu yang tepat guna dan tepat sasaran.

Selama ini berbagai upaya pengembangan kewirausahaan pada kalangan mahasiswa telah digerakkan secara nasional melalui berbagai program yang bersifat intra dan ekstra kurikuler. Program PKM-K yang diluncurkan oleh Ditlitabmas DIKTI setiap tahun secara rutin bertujuan membangun kesiapan mahasiswa muncul sebagai insan wirausaha muda. Meski demikian, berbagai upaya yang dilakukan masih sering menghadapi tantangan baik dari sisi teknis maupun non teknis.

Tantangan yang paling berat dihadapi ketika mengembangkan kewirausahaan pada kalangan mahasiswa bersumber dari keterbatasan keberlanjutan usaha, modal produksi, keahlian kerja, kualitas produk, jaminan pasar produk dan kemitraan yang minim. Tentu saja berbagai permasalahan tersebut merupakan tantangan berat bagi mahasiswa yang ingin mengembangkan jiwa dan semangat wirausaha. Hasil laporan survai pendahuluan kegiatan Tracer Study Universitas Jenderal Soedirman Tahun 2012 menunjukkan pengembangan kewirausahaan pada kalangan mahasiswa sebenarnya mempunyai potensi tinggi karena sekarang ini telah terjadi pergesaran minat dan persepsi mahasiswa, yang semula hanya berminat sebagai pencari kerja (job seeker) beralih menjadi mahasiswa pencipta atau penyedia lapangan kerja (job creator). Tentunya hal ini menjadi sesuatu yang sangat dinanti dan sungguh menggembirakan.

Kesadaran dan minat mahasiswa yang mulai mengalir menjadi insan wirausaha muda menjadi harapan baru dalam mengimbangi jumlah wirausahawan muda di Indonesia yang relatif sedikit dibanding negara lain. Jumlah wirausahawan Indonesia baru mencapai 0,18 persen saja. Sementara, di Singapura terdapat 7,2 persen, Malaysia 3 persen, Filipina 5 persen, Jepang 4 persen (Suryana dan Bayu, 2012). Senada dengan itu, Febriyanto (2014) juga menegaskan, bahwa idealnya Indonesia memiliki dua persen wirausahawan atau setara dengan kurang lebih 5 juta pengusaha. Hal ini diasumsikan jika satu orang pengusaha bisa menyerap lapangan kerja 5 sampai dengan 6 orang saja dari jumlah penduduk miskin, maka negara kita akan terbebas dari kemiskinan dan keterbelakangan.

Persoalannya kemudian adalah bagaimanakah jiwa dan semangat serta perilaku kewirausahaan itu bisa berkembang di kalangan generasi muda khususnya mahasiswa? Jumlah wirausaha yang masih sedikit menunjukkan terdapat missing link dalam difusi program pengembangan kewirausahaan. Oleh karena itu, bahasan pada artikel ini ditujukan untuk mengaji proses pengembangan kewirausahaan pada mahasiswa sebagai suatu alternatif pemecahan masalah bangsa di bidang ketenagakerjaan. Selain itu, bahasan pada tulisan ini juga diupayakan mencari terobosan inovatif yang perlu digerakkan guna mendorong peningkatan minat, kesadaran sekaligus perilaku mahasiswa sebagai wirausaha muda yang produktif, kreatif dan inovatif.

\section{KEWIRAUSAHAAN PENGGERAK MAHASISWA BERKARYA MANDIRI}

Sebuah temuan hasil penelitian yang mencengangkan dikemukakan oleh Ginzberg (2010), bahwa dari 342 responden mahasiswa yang lulus cum laude, summa cum laude dan mereka yang mendapatkan penghargaan atas prestasi akademiknya termasuk Phi Beta Kappa ternyata cenderung hanya berprestasi biasa saja di dunia kerja setelah lulus kuliah. Temuan ini berdasarkan studi yang menguji seberapa jauh keberhasilan responden dalam 
kehidupannya setelah 15 tahun menyelesaikan studi.

Hasil studi ini membuktikan bahwa tidak ada hubungan langsung antara sukses secara akademik dengan sukses dalam kehidupan yang riil (there is no direct relationship between academic success and life success). Inti studi yang dilaksanakan oleh Ginzberg (2010) menegaskan bahwa kunci sukses berkarya dan bekerja produktif terletak pada bagaimana seseorang memandang potensi diri dengan kemampuan kewirausahaan yang unggul. Menurut Ginzberg, konsep diri dalam pengembangan kewirausahaan dapat dianalogikan sebagai sistem operating dalam menjalankan komputer. Jika sistem operating dalam komputer tidak bisa berjalan baik maka komputer akan mengalami error dan akibatnya tidak dapat bekerja maksimum.

Dalam konteks ini disadari bahwa muara dari hambatan yang ada sebenarnya terletak pada keadaan yang masih belum optimal capaian dari kebijakan pendidikan tinggi untuk mengembangkan perilaku kewirausahaan mahasiswa. Dengan kata lain, kebijakan antara level makro dengan praktek pembelajaran di tingkat mikro masih belum sinkron.

Ketidaksinkronan tersebut merupakan salah satu penyebab belum sinergisnya berbagai elemen pendukung pendidikan formal untuk menggairahkan jiwa, semangat dan perilaku kewirausahaan mahasiswa. Kelemahan pengembangan kewirausahaan pada kalangan mahasiswa pada prinsipnya tidak dapat dilepaskan dari metode pembelajaran yang berlangsung secara umum di perguruan tinggi. Chang (2012) seorang pimpinan sektor yang menangani Human Resource. di World Bank membuktikan gambaran distribusi kegiatan dalam suatu innovation class sangat lemah menimbulkan daya kreasi mahasiswa sebagai peserta didik. Keadaan ini mempengaruhi proses pengembangan kewirausahaan mahasiswa. Pada Tabel 1 teramati gambaran distribusi yang dimaksud.

Tabel 1. Gambaran Distribusi Kegiatan dalam Innovative Class

\begin{tabular}{|c|l|c|}
\hline No & Jenis Kegiatan & Persentase \\
\hline 1 & Investigasi & 3 \\
\hline 2 & Kerja Praktek & 10 \\
\hline 3 & Diskusi & 15 \\
\hline 4 & Problem Solving & 20 \\
\hline 5 & Exposisi & 12 \\
\hline 6 & Presentasi belajar sendiri & 10 \\
\hline 7 & Kolaborasi dengan Peers & 10 \\
\hline 8 & Analisis dan Penarikan Kesimpulan & 10 \\
\hline 9 & Refleksi terhadap belajar sendiri & 10 \\
\hline
\end{tabular}

Sumber : Chang (2012)

Berdasarkan informasi pada Tabel 1 di atas, terungkap bahwa sistem pembelajaran yang inovatif mestinya menonjol pada jumlah sesi untuk problem solving dan diskusi serta exposisi diikuti dengan unsur-unsur belajar yang lain. Namun beberapa unsur tersebut tampaknya untuk Indonesia masih lemah karena materi sajian dari pihak dosen lebih dominan. Posisi dosen cenderung tampil sebagai one man show, sedangkan mahasiswa condong menjadi subordinasi dalam proses pembelajaran. Subjek materi yang disampaikan sewaktu proses perkuliahan mayoritas bersifat teoritik. Materi yang membangun inspirasi berkarya relatif minim terutama yang berbasis hasil riset di lapangan. Beberapa permasalahan tersebut akhirnya menjadikan mahasiswa lebih pasif dan daya kreativitas lemah. Keadaan ini menunjukkan bahwa sistem pembelajaran belum mampu merangsang inovasi dan kreativitas mahasiswa. Dominasi peran dosen di beberapa negara dapat dilihat secara lebih 
jelas dari informasi yang tercantum pada Tabel 2.

Tabel 2. Jumlah Kata yang Diucapkan oleh Dosen dan Mahasiswa pada Setiap Pelajaran (Mata Kuliah)

\begin{tabular}{|l|l|l|c|c|}
\hline No & \multicolumn{1}{|c|}{ Negara } & \multicolumn{1}{|c|}{ Pelaku } & $\begin{array}{c}\text { Jumlah Kata dari } \\
\text { Dosen }\end{array}$ & $\begin{array}{c}\text { Jumlah Kata dari } \\
\text { Mahasiswa }\end{array}$ \\
\hline 1 & Indonesia & Dosen/Mahasiswa & 2633 & 197 \\
\hline 2 & Netherland & Dosen/Mahasiswa & 5148 & 766 \\
\hline 3 & Switzerland & Dosen/Mahasiswa & 5360 & 1016 \\
\hline 4 & Chech Republic & Dosen/Mahasiswa & 5452 & 824 \\
\hline 5 & Australia & Dosen/Mahasiswa & 5136 & 810 \\
\hline 6 & Hongkong & Dosen/Mahasiswa & 5798 & 640 \\
\hline 7 & United States & Dosen/Mahasiswa & 5902 & 1018 \\
\hline
\end{tabular}

Sumber : Indonesia Result Combined with Data From Figure 5.14 in Hiebert, J.et.al (2003)

p.109 dalam Chang (2012)

Informasi yang tertuang pada Tabel 2 menunjukkan bahwa ada beberapa faktor yang menjadikan mahasiswa lebih banyak mendengarkan dan menyimak atau bahkan hanya mampu menonton dosen menyampaikan materi secara dominan. Padahal idealnya dalam sistem pembelajaran di perguruan tinggi selayaknya mahasiswa ditempatkan sebagai sentral proses pembelajaran yang dijiwai dengan semangat egalitarian. Bukan lagi diposisikan sebagai objek akibat pada proses perkuliahan di perguruan tinggi masih melekat budaya patronase, feodalisme dan aristokrasi. Sebagai konsekuensinya daya kreativitas dan produktivitas mahasiswa bukannya menguat, namun justeru melemah dan nyaris tak mampu membuahkan "pengetahuan dan inovasi baru" yang dilatarbelakangi perilaku kewirausahaan.

Hambatan lain yang membelenggu semangat kewirausahaan mahasiswa juga datang dari sistem sosial. Hal tersebut misalnya dapat dengan mudah ditemukan berita miring yang memandang rendah orang yang mulai terjun ke dunia usaha, yang notabene syarat dengan penerapan prinsip kewirausahaan.

Opini publik sering merintangi semangat mahasiswa berwirausaha: buat apa sekolah tinggi-tinggi kalau hanya mau jadi wirausaha? Demikian juga masih ada sikap kurang mandiri pada mahasiswa karena mentalitas tidak berani menanggung risiko dan semangat

priyayi yang menempatkan harga diri terlalu tinggi kesemuanya turut andil menghambat pengembangan jiwa, semangat dan perilaku kewirausahaan mahasiswa.

\section{UPAYA PENDORONG PENGEMBANGAN KEWIRAUSAHAAN MAHASISWA}

Keterpurukan sebuah negara bukan hanya disebabkan oleh sumberdaya alam yang mulai menipis, krisis moneter dan rata-rata pendapatan per kapita yang rendah. Akan tetapi, yang lebih penting lagi adalah disebabkan sumberdaya manusia yang lemah dalam menangkal dan mengantisipasi krisis yang terjadi. Pendidikan tinggi dalam hal ini ditantang untuk dapat mencetak sarjana yang memiliki kepribadian dan karakter baik, dengan skill yang mumpuni menjadi ahli bidangnya dan dilengkapi jiwa kewirausahaan. Hal ini sejalan dengan pernyataan McClelland (1961), bahwa states that a society with a generally high level of n.achievement will produce more energetic entrepreneours who, in turn, produce more rapid economic development.

Dengan dibekali kewirausahaan, sarjana dapat menjadi individu yang mandiri sekaligus membuka kesempatan kerja bagi yang lain. Permasalahan bangsa yang menyangkut tingginya jumlah penggangguran terdidik (educated unemployment) merupakan 
tantangan tersendiri bagi perguruan tinggi yang bersangkutan. Sejak dini, di awal seseorang memasuki dunia pendidikan tinggi sudah selayaknya memperoleh kegiatan ekstra kurikuler dilengkapi aktivitas intra kurikuler yang saling menunjang proses sosialisasi kewirausahaan.

Mahasiswa perlu dilibatkan secara partisipatif dalam ceramah interaktif, diskusi terfokus, pelatihan, demonstrasi cara, pameran, magang dan studi banding yang memperkaya perilaku dalam adopsi kewirausahaan. Disamping itu, upaya pembentukan jalinan kemitraan dengan berbagai pihak terkait yang mendukung sosialisasi kewirausahaan pada kalangan mahasiswa perlu terus dilakukan secara intensif. Program lain yang potensial dilaksanakan ialah kampanye nasional yang bergerak dalam rangka memasyarakatkan semangat, jiwa dan perilaku kewirausahaan mahasiswa.

Peran perguruan tinggi dituntut semakin konkrit dalam menggiatkan jiwa, semangat dan perilaku kewirausahaan mahasiswa. Sudah saatnya kewirausahaan untuk mahasiswa bukan lagi hanya slogan belaka. Akan tetapi, yang lebih penting adalah menumbuhkan kesadaran bahwa kewirausahaan bagian integral dan tak terpisahkan dari eksistensi mahasiswa agar dapat bergerak menuju pada suatu kenyataan yang lebih baik. Hal ini tentu perlu didukung bersama oleh semua komponen anak bangsa.

\section{KESIMPULAN DAN SARAN}

Pengembangan jiwa, semangat dan perilaku kewirausahaan pada mahasiswa merupakan salah satu kebutuhan mendasar dan syarat penting bagi Bangsa Indonesia sehubungan dengan tujuan peningkatan kualitas sumberdaya manusia yang produktif, kreatif dan inovatif. Berbagai permasalahan yang merintangi pengembangan kewirausahaan mahasiswa perlu diantisipasi secara bijak dalam rangka menemukan solusi yang tepat. Difusi semangat kewirausahaan pada mahasiswa membutuhkan komitmen dan kerjasama yang integratif antar berbagai pihak terkait. Proses pengembangan kewirausahaan pada mahasiswa perlu dilaksanakan secara berkelanjutan sebagai proses sejak dini memasuki pendidikan di perguruan tinggi, on going sampai mencapai kelulusan sebagai sarjana. Jadikan kewirausahaan sebagai jiwa, semangat dan perilaku mahasiswa pada khususnya dan mentalitas masyarakat Indonesia pada umumnya. Momen ini mestinya jangan sampai terputus dari mulai proses pembentukan mind set dan awareness kewirausahaan, rencana aksi dan praktek kewirausahaan sampai pada tingkat realisasi aksi dan sekaligus evaluasi secara terpadu.

\section{DAFTAR PUSTAKA}

Anonim. 2012. Laporan Tracer Study Universitas Jenderal Soedirman. Purwokerto

Biro Pusat Statistik Republik Indonesia. 2012. Indonesia Dalam Angka. Jakarta

Chang, May Chu. 2012. Nurturing Creativity and Innovation in The Classroom. International Conference on Creativity and Innovation. UNESCO. Hotel Sulthan. Jakarta.

McClelland, David C. 196I. The Achieving Society. Mc Graw Hill Company. New York.

Suryana, Yuyus dan Khatib Bayu. 2013. Kewirausahaan - Pendekatan Karakteristik Wirausahawan Sukses. Kencana Prenada Media Group. Jakarta.

\section{Sumber lain :}

Febriyanto dalam wordpress.com. 2014
Ginzberg,
Eli.
2010
dalam http://ya2n67.blogspot.com/2010/06/do-you-knowbig-secret-to-success-of.html.

Di download Tanggal I2 Oktober 2014. 